\title{
The Impact of Underage Marriages on Family Welfare
}

\author{
Yusma Natasya Perdana1*, Abidin Abidin ${ }^{2}$, Kamaruddin Kamaruddin ${ }^{3}$
}

${ }^{1}$ Islamic Family Law Department, Postgraduate, Institut Agama Islam Negeri Palu

2 Islamic Family Law Department, Postgraduate, Institut Agama Islam Negeri Palu

3 Islamic Family Law Department, Postgraduate, Institut Agama Islam Negeri Palu

\begin{abstract}
This study examines the Impact of underage marriages on household welfare. The phenomenon of early marriage in Indonesia has attracted attention from scholars and practitioners. This study employed a qualitative method. The data were collected through direct observation, in-depth-interviews, and written document analysis. Data analysis was conducted through reduction techniques, data presentation, data verification, and conclusion drawing. The results of this study showed that the level of wellbeing of early marriage were included in the category below the establishment line of life both financially and spiritually. Factors causing changes in welfare include mindset, mental, and spiritual which is immature in family management causing a loss of the real purpose of building well-being and happiness families. The implication of this study was seen from Islamic law. Even though under ages marriage is legal in Islamic law perspective, but the marriage is not legal from government las perspectives. Underage marriage caused negative impact of family wel-being and happiness.
\end{abstract}

\section{ARTICLE \\ INFORMATION}

Keywords:

Under ages marriage, family welfare, Islamic law, social impact 


\section{Introduction}

Marriage is a bond that protects humanity from things that can get closer to actions that can violate existing rules. It is the nature of God, that two human beings of different sexes, namely a man and a woman, have the same desire to know, observe, and love each other, even with this that brings humans to continue the relationship in a marriage bond.

Marriage is not only a very noble way to regulate domestic life and offspring, but to love each other both from both parties and to all families so that they become one in all matters, helping each other in doing good and preventing evil. In addition, with marriage, a person will be protected from the destruction of his lust. ${ }^{1}$ Marriage can also be said to be a sacred agreement between a man and a woman to form a happy family. The agreement ${ }^{2}$ is stated in the form of ijab qabul pronounced in an assembly, either directly by prospective husband and wife.

Law No. 1 of 1974 explains in detail the minimum age for brides, where the age of marriage for women is 16 years, while the age for men is 19 years. However, the reality often shows that many marriages occur at the age of under 18 years.

The ideal age for marriage is seen from the maturity of the attitude of the

\footnotetext{
1Falah Saebani, Hukum Perdata Islam di Indonesia (Bandung: Pustaka Setia, 2011), 36.

2 See Haerunnisa Yunus, Rusli Rusli, and Abidin Abidin, "The Concept of A Marriage Agreement in the Compilation of Islamic Law," International Journal of Contemporary Islamic Law and Society 2, no. 2 (2020): 33-45.
}

couple who will marry themselves, in addition to sufficient material preparation. However, in general, children who are considered mature enough to marry are over the age of 18 for women and 20 years for men. ${ }^{3}$ However, this is different from the marriage law No. 1 of 1974, which stipulates that the age limit for a man and a woman who will enter into a marriage is only permitted if they have reached the age of 19 years for men and for women who have reached the age of 16 years.

If you have not reached the age required by law, then you must obtain permission from your parents or guardian which is manifested in the form of a permit as one of the requirements to enter into a marriage. And even candidates who are less than 16 years old must obtain a dispensation from the court. ${ }^{4}$ Sometimes there are also women over the age of 20 who are just adults and also men who are 25 years old, but surely between the ages of 18-25 years is the age that is considered sufficient for marriage in terms of age and mental and physical maturity. However, for ordinary people, the issue of age is not too ignored, the important thing is that they already have a partner and feel there is a match between them, then they are immediately married, even though in terms of age they are still under sixteen years old.

The phenomenon of underage marriage is still very high, not only in rural areas, but also in big cities in

\footnotetext{
${ }^{3} \mathrm{Abu}$ Al-Gifari, Badai Rumah Tangga (Bandung: Mujahid Press, 2003), 132.

${ }^{4}$ Zuhdi Muhdlor, Memahami Hukum Perkawinan (Bandung: Al-Bayani, 1995), 18-19. e-ISSN: $2715-4580$ p-ISSN: $2715-8268$
} 
Indonesia. This phenomenon of underage marriage seems to be a recurring "fashion". In the past, underage marriage was considered normal for various reasons, now many teenagers want to get married young. Among teenagers, underage marriage is considered as a way out to avoid free sex. There are also those who do it out of necessity and get pregnant out of wedlock. This opinion may be true, but marriage is certainly not just uniting in a marriage as an answer to the problems of life that are being faced. Marriage is a provision of life that must be prepared carefully.

\section{Literature Review}

\subsection{The factors of underage marriage}

According to Sibagariang, the factors that cause underage marriages include: ${ }^{5}$

a. Parents are worried about being disgraced because their daughter is dating a man who is very close, so they immediately marry off their son.

b. Social and cultural factors. In various regions, there are those who think that women aged 17 are considered spinsters if they are not married. Marriage at a young age occurs because parents are afraid that their child will be called an old virgin so they are immediately married.

c. Economic factor. Parents assume that if their daughter has been proposed and will be married, at least she will no longer depend on her parents,

\footnotetext{
${ }^{5}$ Sibagariang, Kesehatan Reproduksi Wanita (Jakarta: Trans Info Media 2010), 25.
}

because there is already a husband who is ready to provide for her.

d. Educational factor. Women have less opportunity to get formal education and work, thus influencing them in their decision to postpone marriage.

e. Environmental and association factor. It is undeniable; there are still marriages at a young age that occur because they are pregnant during courtship.

f. Mass media factor. The incessant exposure of sex in the mass media causes modern teenagers to be increasingly permissive of sex.

The interesting thing about underage marriage in Indonesia is that there is a significant comparison between rural and urban areas. Based on the 2005 Intercensus Population Survey (SUPAS) analysis from the National Family Planning Coordinating Board (BKKBN) it was found that the marriage rate in urban areas was lower than in rural areas, for the age group 15-19 years. The difference is quite high, namely $5.28 \%$ in urban areas and $11.88 \%$ in rural areas. This shows that young women in rural areas are more likely to marry at a young age. ${ }^{6}$

\subsection{Impact of Underage Marriage}

Marriage at a young age will have an impact on both the couple and the

\footnotetext{
'Imfatul Tria Nur Azizah, "Pernikahan dini sebagai masalah sosial-kesehatan masyarakat Indonesia" dalamhttp://imfatul-triafkm13.web.unair.ac.id/artikel_detail-92162sosial\%20kesehatan-

Pernikahan\%20dini\%20sebagai\%20masalah\%20s osialkesehatan\%20masyarakat\%20Indonesia.html Accessed: 4 May 2018.

e-ISSN: $2715-4580$ p-ISSN: $2715-8268$
} 
family. According to M. Fauzi Adham, there are several impacts of young marriage. First, the husband and wife do not know and carry out properly their rights and obligations as husband and wife. This is because they are physically and mentally immature, which tends to lead them to a high selfish attitude.

In addition, the impact of marriage at a young age is on their children. For women who get married under the age of 20 years, if they are pregnant, they will experience disturbances in their womb. Furthermore, it also has an impact on each of their families. If the marriage between their children runs well, it will certainly benefit their respective parents. However, if otherwise, a divorce will occur. This will result in an increase in their cost of living, and worst of all, the the ties of kinship between the two parties will severe. ${ }^{7}$

\section{Methodology}

This study uses qualitative approach $^{89}$ investigating the impact of

${ }^{7}$ Laily Purnawati, Skripsi: Dampak Perkawinan Usia Muda Terhadap Pola Asuh Keluarga (Studi Di Desa Talang Kec. Sendang Kab. Tulungagung) (Tuluang Agung: Iain Tulung Agung,2000), 6-7.

8 Nurdin, N., \& Yusuf, K. (2020). Knowledge management lifecycle in Islamic bank: the case of syariah banks in Indonesia. International Journal of Knowledge Management Studies, $11(1)$, 59-80. https://doi.org/10.1504/ijkms.2020.105073; See also Rusli Rusli, "Pendekatan Fenomenologi Dalam Studi Agama Konsep, Kritik Dan Aplikasi," Islamica: Jurnal Studi Keislaman 2, no. 2 (2008): 141-153.

9 Rusli, R., \& Nurdin, N. (2021). Understanding Indonesia millennia Ulama online knowledge acquisition and use in daily fatwa
Underage Marriages on Family Welfare. The study was carried out in Palu city which focused on under ages married families. Data were collected through field observation, in-depth interviewes with under age's families' members. Written materials were also used to analyze the case. ${ }^{10^{\prime} 11}$ We also interviewed under ages divorced families members to understand their experiences. Data analysis consists of several procedures which included reduction and verification techniques with various data sources. ${ }^{12}$ The reduced data is then analyzed reflecting on theoretical concepts used in this study ${ }^{13}$.

\section{Result and Discussion}

making habits. Education and Information Technologies. https://doi.org/10.1007/s10639021-10779-7

${ }^{10}$ Nurdin, N. (2021). A Collective Action In Indonesia Local E-Government Implementation Success. International Journal of Scientific $\mathcal{E}$ Technology Research, 10(2), 160-166.

11 Nurdin, N. (2018). Institutional Arrangements in E-Government Implementation and Use: A Case Study From Indonesian Local Government. International Journal of Electronic Government Research (IJEGR), 14(2), 44-63. https://doi.org/10.4018/ijegr.2018040104

12 Muslih, Imam, Nurdin, Nurdin, \& Marzuki, Marzuki. (2020). Effectiveness of Marriage Services Through Information System Management (SIMKAH) at Palu City Religious Court International Journal Of Contemporary Islamic Law And Society, 2(1), 20-35.

${ }^{13}$ Iqbal, M., Rusli, R., \& Musyahidah, M. (2019). Management Strategies of Professional Zakat Funds for Mustahiq Family Welfare By Amil Zakat Body International Journal of Contemporary Islamic Law And Society, 1(1), 39-51.

e-ISSN: 2715-4580 p-ISSN: $2715-8268$ 


\subsection{Causes of underage marriage}

In accordance with the Law of the Republic of Indonesia Number 23 of 2002, a child is defined as someone who is not yet 18 years old, including those who are still in the womb. Children automatically do not have the ability to give consent so child marriage is considered to violate the marriage rules that require conscious consent from both parties. $^{14}$

According to Irmayanti, from the report of the Office of Women's Empowerment and Child Protection in Palu, the data shows that the child marriage rate in Palu City is still quite high, where the average data is that children aged 15-19 years are married or already married. The largest percentage of child marriages is in Banggai Laut at 15.83 percent followed by Banggai Laut district at 15.73 percent, Sigi district at 13.77 percent, then Tojo Una-una district at 12.84 percent, and Palu city at 6.90 percent. Central Bureau of Statistics survey data shows that in 2015, the age at first marriage or underage marriage in Central Sulawesi was still very high, believed to be 20.19 percent of all regions in Central Sulawesi. For the city of Palu in 2017 it reached 100 children. ${ }^{15}$

The reasons behind underage marriage based on the interview include

\footnotetext{
${ }^{14}$ Rusli Rusli, "An Analysis of Islamic Feminism in Indonesia: Reconstruction of Islamic Legal Issues on Gender Relations", HUNAFA: Jurnal Studia Islamika 3, no. 1 (2006), 1-12; see also, Rusli, Islamic Feminism: Responses of Muslim Feminists to Gender Inequality in Indonesia (Palu: Irshed Press, 2006).

15Interview with Irmayanti Pettalolo, 11 August 2019.
}

internal and external factors. Internal factors include the family, especially parents. Parents play an important role in the decisions taken by the child. The assumption that child marriage occurs because of economic pressure or parental encouragement is not entirely true.

The other factors include the desire to avoid domestic violence involving parents, and pregnancy outside of marriage is the most common cause in Indonesia, when a man and a woman know each other and create feelings of love that leads to forbidden sex outside marriage.

There are also those who do it because they are abandoned by their parents or left out of town or country. There is also an inadequate economic reason, which usually triggers parents to immediately marry off their children to wealthy officials in order to be able to increase their family's economic problems. Most parents want their children to live more settled than them, but their way is sometimes wrong, because there are other better ways than having to marry off their children at the age that is said to be underage.

"I think, after marriage my life is happy. And I want to be able to live independently without any help from my parents. At least, now I'm not a burden to my parents, because I'm married and someone is paying for my life, even though at first to live independently and get used to being dependent on my parents is not easy, slowly, God willing, I can adjust". ${ }^{16}$

16Interview with Sonatria, 18 July 2019. e-ISSN: 2715-4580 p-ISSN: 2715-8268 
Not a few people who are married change their attitudes and behavior without realizing it because of marriage. As stated by the first informant.

"Regarding behaviour, of course, I'm now more mature in dealing with various problems. Get to know each character better, so you have to be more patient in dealing with problems. Because when you are married, usually unimportant issues are exaggerated, there is a lack of a partner that is not in accordance with the heart is questioned again, we assume that what the partner does is not in accordance with what we want. When both are emotional, it causes a quarrel. Only one of us has to give in and be silent." 17

The same also applies to the second informan, who did underage marriage. She argued,

"I married because I felt I was ready. I do not want to fall into promiscuity at this time. On the other hand, people talk about men and women who often go out together is also not good. That's the reason that made me decide to get married at a very young age" ${ }^{18}$

She continued,

"The desire to get married at an early age arises from within, without any coercion from any party, everything is purely a desire

${ }^{17}$ Interview with Sonatria, 18 July 2019.

${ }^{18}$ Interview with Sonatria, 18 July 2019. of the two of us personally, and my husband and I thought if we both like it, why should we linger in a relationship that might plunge us"19

The role of parents in the family is very decisive and influences the mindset of children. Their role is a primary teaching. Of course, every parent has a different parenting style. This difference also has an impact on the development and formation of children's character.

Children have characters that can be seen from childhood to adulthood according to experience or whatever they experience. Of course, this cannot be separated from the influence of parents who shape the child's character through teaching or by giving direct examples of the actions taken. Likewise, the way parents make decisions, will have an impact on children to make decisions based on patterns of influence and teaching based on family, especially their parents.

\subsection{Impact of Underage Marriage on Household Welfare}

Finances become a complicated issue when two people are united in a marriage bond. Openness between husband and wife is an important factor that determines the integrity of the household. In family life, there will be difficult times, such as financial crisis. This is what is called household dynamics. Sonatria said,

"So far, what my husband gave me was only enough to eat. It can only

${ }^{19}$ Interview with Santi, 18 July 2019.

e-ISSN: $2715-4580$

p-ISSN: 2715-8268 
meet the needs of food each day. That's still not enough. Money Rp. $20,000-$, I can only buy rice to meet his daily needs, because my husband works as a construction worker". ${ }^{20}$

Some people think that economic problems are synonymous with lack of money. This a condition where the family is unable to provide for their basic needs. Economic problems are one of the factors that have been proven to destroy family happiness.

The first attitude that a married couple must have is to face economic problems together. Husband and wife must be on the same side when facing economic problems in the family. After marriage, husband and wife must become a solid team, including in dealing with life's problems.

Thus, both parties feel responsible for finding solutions to the family's economic problems with their respective portions based on what they can do. By not blaming each other for the economy, it will further complicate the household situation.

After listening to the statements made by the informants, the author can draw a conclusion in terms of welfare. Judging from the explanation, Sonatriya has problems in the economic field. Her husband is only able to meet the needs of family life no more to meet food needs. As a wife, Sonatriya does not want to blame the situation and her husband. For that, Sona helps her husband work by

\footnotetext{
20Sonatria, "Wawancara", Informan Pelaku Pernikahan Dibawah Umur, (18 Juli 2019)
}

becoming a laundry worker to help the family's economy.

As for the second informant, it is not much different from the first informant. Santi said,

"In terms of economic welfare, all needs have not been met. Because my husband is just a rough construction worker and market labour. So to meet the needs of life is still far from feasible. Sometimes my husband doesn't work. We only rely on my husband's income to meet all the necessities of life" ${ }^{\prime 21}$

After hearing the explanation given by the second informant, the author can conclude that the concept of welfare in marriage is based on love, and the reason of marriage is to avoid sins that will arise. From a financial point of view, it is also very limited because the husband is only a rough construction worker and sometimes he does not work. However, marriage is based on a foundation of faith and mental readiness so the can achiev happiness in household.

Welfare itself has many meanings where each person must have their own perspective on what is called welfare. However, in general, welfare itself can generally be divided into two forms, namely material welfare and nonmaterial welfare. What assets we have, how much income we get, and what can be materialized. While non-material welfare is is not in the form of goods or the like, but in the form of health, piety, and pious children.

\footnotetext{
${ }^{21}$ Santi, "Wawancara", Informan Pelaku Pernikahan Dibawah Umur, (18 Juli 2019)

e-ISSN: 2715-4580 p-ISSN: 2715-8268
} 
The next informant is Erni. He said that the well-being he felt was not very visible. Because to meet the needs of his life he still asks his parents. Meanwhile, her husband has yet to find a job. The husband promised to work, but until now he still hasn't found a job that suits him.

"I have not felt well-being from an economic point of view. My husband is not working yet, so to meet the needs of life I still rely on my parents. I want to be independent, but I don't know where to start again. I used to work in a state-owned company; my income at that time was high. However, when there were massive layoffs, I became one of the employees who were fired. After that I haven't worked until now" 22

The welfare of a person's life in reality has many indicators that can be measured. Measurement of a person's level of welfare also often changes from time to time. If you look at the example of the case in the fourth informant, the welfare that he feels after getting married is not obtained. Good welfare which includes peace of mind and body and mind

Meanwhile, according to the last informant, Sukma, he said things were not much different from other informants that the researcher interviewed.

"I haven't received any prosperity in the economic field. My husband works as a traveling somay trader. But to meet the needs of life, I have

22Interview with Erni, 18 Juli 2019. not really felt. There are still many needs that I want to buy but can't be fulfilled. Everyone is still starting from the bottom. For me, being prosperous is in a sufficient economic condition". ${ }^{23}$

\section{Conclusions}

Underage marriage has several impacts on people's lives, especially for the perpetrators. Although there are positive impacts in underage marriage, there are not a few negative impacts. Most of the consequences are bad, even causing various problems which lead to divorce in religious courts. Bad consequences that often arise are due to the immature age and maturity of the perpetrators of underage marriage.

Regarding the level of welfare of someone who does early marriage is included in the category below the established life line. When viewed from Islamic law, it is religiously valid, referring to Q.S Surat An-Nur. In Islam indirectly maturity is not so important. The signs of a person's maturity are determined by physical characteristics with signs of balig (mature). while in state law with the legal basis of marriage law no. 1 of 1974 has not been allowed until the age of marriage is allowed, up to the limit of a 19 year old male and 16 year old female.

The welfare of five informants who married underage in general in their married life, said they did not experience welfare in their lives. Four of them still survive in their household even though they live in economic limitations. One of

${ }^{23}$ Interview with Sukma, 20 Juli 2019. e-ISSN: $2715-4580$ p-ISSN: $2715-8268$ 
them has divorced, and one of them has kept his marriage even though he has experienced domestic violence. Factors causing changes in welfare include immature mindsets, mental and spiritual in navigating the household ark, causing the loss of the real goal of building a sakinah, mawwadah and warrahmah household.

\section{REFERENCES}

Abdurrahman. Kompilasi hukum islam di indonesia. Cet. II. Jakarta: CV. Akademika Persindo, 1995

Al-Azhar, Mudzakaroh. Perkawinan di BawahUmur. Jakarta: Khittih, 2010

Al-Ghifari, Abu. Badai Rumah Tangga. Bandung : Mu jahid Press, 2003

Al-Qarni, Aidh.Tafsir Muyassar Jilid.4. Jakarta:QisthiPress,2007

Ash-Shiddieqy, Teungku Muhammad Hasbi. Al-Islam Kepercayaan KesusilaanAwal Kebajikan .Jakarta:Bulan Bintang, 1969.

Bachtiar, Wardi. Metode Penelitian Ilmu Dakwah Cet.I. Jakarta: Logos, 1997

Bagir,M.Fiqih

Praktis.

Bandung:Mizan,2002

Beranda Hukum, Https:// berandahukum. Com/2016/04/ asa-asas perkawinan.html, diakses pada tanggal 13 September 2019

Bungin, Burhan. Metodologi Penelitian Kualitatif. Jakarta: Kencana Prenada Media Group, 2003

Cahyadi, Tarkariwan. Pernak-Pernik Rumah Tangga Islam:Tatanan danPerayaannya Dalam Masyarakat. Solo:Inetermedia 1997
Darmabarata, Wahono. Tinjauan Undangundang No. 1 Tahun 1974 tentang Perkawinan dan undang-undang dan peraturan pelaksanaanya. Yogjakarta: CV. Gita Maya Jaya, 2003

Dawud,M. Hukum Islam dan Perdilan Agama. Bandung:Trigenda Karya,1996

Departemen Agama RI. Membina Keluarga Bahagia Sejahtera. Jakarta:DepagRI, 1998

Kementerian Agama RI.Al-Quran dan Terjemahmnya. Jakarta : Al-Huda, 2009

Departemen Pendidikan Nasional. Kamus Besar Bahasa Indonesia. Cet.II, Jakarta: Balai Pustaka, 2005

Depdikbud.Kamus Besar Bahasa Indonesia. Jakarta:Balai Pustaka, 1999

Erni, "Wawancara" Informan pelaku pernikahan Anak dibawah umur, (20 Juli 2019)

Fitrianingsih, Rani. Skripsi: Faktor-faktor Penyebabnya Pernikahan Usia MudaPerempuan Desa Sumber danti Kec. Sukowono Kab. Jember. Jember: Universitas Jember, 2015

Ghifari, Abu. Gelombang Kejahatan Seks Remaja Modern,cet. ke-4. Bandung: Mujahid, 2003

Hadi,Sutrino.Metodeologi Reasearch.

Yogyakarta: Andi, 2004

Hadikusuma, Hilman. Hukum Perkawinan Indonesia,Cet.Ke-1.

BandarLampung:Mandar Maju,1990 Haerollah, wawancara Kepala Urusan Agama Palu Barat tanggal 05 Oktober 2019

Hamdani.Risalah Hukum Perkawinan Islam.Jakarta:Citra Karsa Mandiri,1995

e-ISSN: 2715-4580 p-ISSN: 2715-8268 
Haroen, Nasrun. Kajian Fikih Kontemporer. Jakarta: Gema Press,2001

Iqbal, M., Rusli, R., \& Musyahidah, M. (2019). Management Strategies of Professional Zakat Funds for Mustahiq Family Welfare By Amil Zakat Body International Journal Of Contemporary Islamic Law And Society, 1(1), 39-51.

Kartini, "Wawancara" Informan pelaku pernikahan Anak dibawah umur, (18 Juli 2019)

Kilis, Grace.Dinamaika Konflik Suami Istri Pada Masa Awal Perkawinan. Jurnal PsikologikaVolume19No2Tahun201 4

Majda,ElMuhtaj Dimensi-dimensi HAM mengurai hak ekonomi,sosial, dan budaya. Jakarta.PT.Raja grafindo Persada 2009

Maloko, M. Thahir . Dinamika Hukum dan Perkawinan. Cet. I ; Makassar: Alauddin University Press, 2012

Mardiyah. "Mewujudkan keluarga Sejahtera dalam Perspektif Islam", diakses 23 Mei 2018

Marzuki. Metodologi Riset. Yogyakarta: FE. UI, 1989

Milles, Metthew B dan Hubarman, A. Michael. Qualitative Data Analisis, diterjemahkan oleh Tjecep Rohendi, Analisis Data Kualitatif. Buku Tentang Metode-metode Baru, Cet.I. Jakarta: UI Press, 2005

Moleong, Lexy J. Metodologi Penelitian Kualitatif, Cet. XVII. Bandung: PT. Remaja Rosdakarya, 2002

Mongid, A. Gerakan Pembangunan Keluarga Sejahtera. Jakarta: BKKBN, 1995
Muhdlor, Zuhdi. Memahami Hukum Perkawinan. Bandung : Al

Bayani, 1995

Muslih, Imam, Nurdin, Nurdin, \& Marzuki, Marzuki. (2020). Effectiveness of Marriage Services Through Information System Management (SIMKAH) at Palu City Religious Court International Journal Of Contemporary Islamic Law And Society, 2(1), 20-35.

Nasution, S. Metode Penelitian Kualitatif. Bandung: Tarsito, 1992

Nurdin, N. (2018). Institutional Arrangements in E-Government Implementation and Use: A Case Study From Indonesian Local Government. International Journal of Electronic Government Research (IJEGR), 14(2), 44-63. https:// doi.org/10.4018/ijegr.2018 040104

Nurdin, N., \& Yusuf, K. (2020). Knowledge management lifecycle in Islamic bank: the case of syariah banks in Indonesia. International Journal of Knowledge Management Studies, 11(1), 59-80. https://doi.org/10.1504/ijkms.2020 .105073

Nurdin, N. (2021). A Collective Action In Indonesia Local E-Government Implementation Success. International Journal of Scientific \& Technology Research, 10(2), 160-166.

Paramita, Pradnya. KitabUndangundangHukumPerdata(BurgelijkWetbo ekcetakanke27).Jakarta: Gema Press, 1976

Peraturan Menteri Agama No. 11tahun 2007 tentang Pencatatan Nikah Bab IV 
International Journal of Contemporary Islamic Law and Society

Vol. 3 No. 2 Tahun 2021

Prastowo,Andi.Menguasai Taknik-teknik Koleksi Data Penelitian Kualitatif (Bimbingan dan Pelatihan Lengkap Serba Guna), Cet.I. Jogjakarta: Diva Press, 2010

Purnawati, Laily. Skripsi: Dampak Perkawinan Usia Muda Terhadap Pola Asuh Keluarga (Studi di Desa Talang Kec. Sendang Kab. Tulungagung). TulungAgung: IAIN Tulung Agung, 2000

Ramulyo, Mohd. Idris. Hukum Perkawinan, Hukum Kewarisan, Hukum Acara Peradilan Agama, dan Zakat menurut Hukum Islam. Jakarta: Sinar Grafika, 1995

Rasjid, Sulaiman. Figh Islam. Bandung: SinarBaruAlgensindo, 2010

Rofiq, Ahmad. Hukum Islam diIndonesia. Jakarta:Raja Grafindo Persada, 2000.

Rusli, Islamic Feminism: Responses of Muslim Feminists to Gender Inequality in Indonesia (Palu: Irshed Press, 2006).

Rusli Rusli, "An Analysis of Islamic Feminism in Indonesia: Reconstruction of Islamic Legal Issues on Gender Relations", HUNAFA: Jurnal Studia Islamika 3, no. 1 (2006), 1-12.

Rusli Rusli, "Pendekatan Fenomenologi Dalam Studi Agama Konsep, Kritik Dan Aplikasi," Islamica: Jurnal Studi Keislaman 2, no. 2 (2008): 141-153.

Rusli, R., \& Nurdin, N. (2021). Understanding millennia Ulama online knowledge acquisition and use in daily fatwa making habits. Education and Information

Technologies. https://doi.org/10.1007/s10639-

021-10779-7

Sabiq,Sayyid. Fiqh Sunnah, Juz VI. Bandung: PT.AlMa'arif,2000

Sholeh. Pernikahan Usia Dini Perspektif Munakahah Dalam Ijma Ulama.Jakarta: Majelis Ulama Indonesia, 2009

Sibagariang.Kesehatan Reproduksi Wanita. Jakarta: Trans Info Media 2010

Soemiyati. Hukum Perkawinan Islam dan Undang-undang Perkawinan.

Yogyakarta: Liberty

Yogyakarta,1986

Strauss, Anselmand Juliet Corbin, Basics Of Qualitative Research grounded theory procedures and techniques, diterjemahkan Djunaidi Ghony dengan judul Dasar -Dasar Penelitian Kualitatif Prosedur, Teknik, Dan Teori Grounded. Surabaya : PT Bina Ilmu Ofset, 1997 Sudarsono.Hukum Kekeluargaan Nasional. Jakarta: Rineka Cipta, 1991

Sukma, "Wawancara" Informan pelaku pernikahan Anak dibawah umur, (20 Juli 2019)

Sugiyono. Memahami Penelitian Kualitatif . Bandung: Alfabeta, 2007

------. Metode Penelitian KualitatifKuantitatif dan RED. Bandung: Alfabeta, 2006

Sukardi. Penelitian Pendidikan Kompetensi dan Praktiknya, Cet.VI. Jakarta: PT. Bumi Aksara, 200

Sukmadinata, Nana Syaodih. Metode Penelitian Pendidikan. Bandung: PT.Remaja Rosdakarya, 2005 
Surachmad, Winarno. Penelitian Ilmiah, Dasar, Metoda dan Teknik. Bandung: Tarsito, 1990.

Suwondo, Nani. Hukum Perkawinan dan Kependudukan di Indonesia. Bandung: PT. Bina Cipta, 2008

Syarifuddin,Amir. Garis-garis Besar Figh. Jakarta: Kencana,2003

Syarifuddin, Amir.Hukum Perkawinan Islam diIndonesia: Antara FiqihMunakahat dan Undang- undang Perkawinan. Jakarta: Prenada Media, 2006

Santi, "Wawancara" Informan pelaku pernikahan Anak dibawah umur, (18 Juli 2019)

Sonatria, "wawancara", informan pelaku pernikahan Anak dibawah umur, (18 Juli 2019)

Umar, Husein. Metode Penelitian untuk Skripsi dan Tasir Bisnis, Cet. IV. Jakarta: PT. Raja Grafindo, 2000 